https://doi.org/10.52505/filomod.2021.15.39

\title{
TRADUCEREA ÎN VIZIUNEA LINGVISTICII INTEGRALE
}

\author{
Angela SAVIN-ZGARDAN \\ Institutul de Filologie Română „B. P.-Hasdeu” al MEC
}

\begin{abstract}
Rezumat. Viziunea traducerii este privită prin prisma lingvisticii integrale a lui Eugeniu Coșeriu, care vine cu argumente în favoarea unei lingvistici a celor trei niveluri ale limbii înțelese ca trepte ale cunoașterii lingvistice: lingvistica limbii, a vorbirii și a textului. În articolul de față se face o analiză a fidelității traducerii versus temporalitatea în baza unei monografii recent apărute, consacrate traducerii.

Cuvinte-cheie: lingvistica integrală, sens, pragmatică, traducere, limbă, vorbire, text.
\end{abstract}

Abstract. Eugeniu Coseriu's vision of translation is seen through the prism of integral linguistics, which comes with arguments in favor of linguistics of three language levels understood as stages of linguistic knowledge: the linguistics of language, speech and text. This article analyzes the fidelity of the translation versus the temporality based on a recently published monograph, dedicated to translation.

Keywords: integral linguistics, meaning, pragmatics, translation, language, speech, text.

Fidelitatea sau infidelitatea traducerii , în viziunea contemporană, cere de la traducător competențe de nivel gnoseologic și ontologic care se referă la diverse ramuri ale lingvisticii. Un traducător bun, la ora actuală, trebuie să fie competent cu privire la echivalența sau nonechivalența, sinonimia sau non-sinonimia faptelor glotice la nivelul limbii, la cel al vorbirii sau la cel al discursului. În această ordine de idei, vom aborda acest subiect, reflectat în monografia doamnei Irina Breahnă O abordare traductologică a calculului inferențelor direcționale (în baza unui studiu experimental). (Chișinău: CEP USM, 2021.273 p.)

În lucrarea de faţă, în mod just, este delimitat obiectul de studiu, făcându-se o demarcare între diferite niveluri ale limbii și anume: problematica sensului care este centrală pentru lingvistica modernă nivelul limbii; determinarea locului și modului prin care sensul este generat, reconceptualizarea idiomului din instrument de codificare în instrument de reprezentare și de comunicare - nivelul vorbirii, utilizarea diverselor modele de enunțuri, utilizând gramatica generativ-transformațională, plasându-le într-un şir conceptual - nivelul vorbirii și al discursului. Astfel, autoarea Irina Breahnă în studiul dumisale aplică concepția de lingvistică integrală ce îi aparține marelui lingvist Eugeniu Coșeriu. 
Teoria pertinenței (TP) propune principiul pertinenței drept instrument regulator al comunicării verbale, reușind să explice cum oamenii comunică, dar și de ce comunicarea umană se soldează uneori cu eșec. TP relevă importanţa proceselor de contextualizare în derivarea sensului.

În monografia dată este aplicat Modelul Inferențelor Direcționale (MID) pentru limba română. Acest procedeu de lucru a fost elaborat de „Grupul de cercetare privind referința temporală" de la Universitatea din Geneva, sub conducerea lui J. Moeschler. Folosind acest instrumentar de lucru, autoarea a formalizat rezultatele obținute în cadrul unei subunități de traducere direcțională. În urma acestei investigații s-au constatat anumite tendințe și realizări cu privire la aoristizarea perfectului compus în română și valoarea de inversiune temporală obținută cu ajutorul lui. De asemenea, rezultatele obținute în domeniul traducerii au permis propunerea unui model teoretic al subunității de traducere direcțională (sUTd). TP s-a dovedit a fi un cadru teoretic cu valoare descriptivă și explicativă, iar Modelul Inferențelor Direcționale (MID) a oferit instrumentarul și metalimbajul necesar pentru tratarea subiectelor particulare legate de temporalitate. Au fost demonstrate experimental prevederile MID, ceea ce a condus la clarificarea particularităților calculului inferențial direcțional în limba română, creând baza teoretică pentru formalizarea unui model de subunitate de traducere direcțională. În prezentul studiu a fost validat pe cale experimentală Modelul Inferențelor Direcționale pe materialul limbii române și determinarea particularităţilor generate de calculul inferențelor direcționale în această limbă. Autoarea plasează calculul inferențial în aplicarea traductologică, prin formalizarea unei subunități de traducere direcțională.

Deasemenea,în cercetarea de față esteidentificată categoria temporalitătii, modalitatea de elaborare a MID, în ce măsură pragmatica postgriceeană și TP au contribuit la fundamentarea sa teoretică, desfășurarea celor două etape de validare experimentală a MID, determinarea modelului teoretic de subunitate de traducere direcțională (sUTd) și trăsăturile fundamentale ale ei.

Noi, făcând trimitere la lingvistica integrală a lui Coșeriu, nu putem să nu menționăm că în toată canavaua tezei găsim repere ce fac trimitere la conceptul dat. De pildă, la formularea ipotezelor, autoarea abordează problematica limbii, reflectată în gramatica funcțională, reiterând că - sUTd constituie un proces inferențial specializat, subordonat ierarhic procesului inferențial general care produce forma propozițională a enunțului;

- problematica vorbirii, reflectată în gramatica generativtransformațională, o putem referi la calculul inferenței direcționale care are loc în timpul procesului de traducere; la greșeala de traducere; la mecanismul fundamental al sUTd de funcționare care este în esență inferențial, de natură pragmatică;

- problematica lingvisticii cognitive se aplică la sUTd care este un concept universal transglotic, deoarece conținutul său poate fi definit în termeni de informații procedurale și conceptuale purtătoare de trăsături direcționale. 
Conform teoriei lui Eugeniu Coșeriu, funcția semnificativă, adică semnul, semnificația limbii e cea primordială. Pe când, după R. Jacobson, limba e pragmatică, e cod și autoarea prezentului studiu se află pe poziția de interferență între teoria lui Jacobson și cea a lui Coșeriu. Coșeriu îl contrazice pe Jacobson, afirmând că limba nu e cod, ci e concept, care e tipic omului, doar el implică semnificație în redarea informației. Coșeriu, situându-se pe poziția lui Humbold, afirmă că limbajul are funcție creatoare, de instituire a semnificației, fiecare limbă având semnificația sa. Eugeniu Coșeriu vine $\mathrm{cu}$ argumente pentru cele trei niveluri ale limbii ca trepte ale cunoașterii lingvistice: limbă, vorbire și text (Coșeriu, 2013, p. 70-79)

Ceea ce observăm în prezenta teză este că MID operează atât cu codul, oferind anumite modele structural-semantice, dar și cu semnificaţia, la nivel de limbă, dar și cu sensul, la nivelul vorbirii, realizate prin diverse modele ale frazemelor. De asemenea, în prezentul studiu se propune o serie de termeni pentru domeniul investigat al lingvisticii care sunt fie traduși, fie actualizați, fie adaptați la structura limbii române.

Autoarea face o sinteză a problemelor care au definit domeniul temporalității în limbă, o categorie filosofică și lingvistică vastă ce incorporează atât diverse teorii, cât și multe aspecte ale manifestării sale. Una din aceste manifestări ar fi aspectul în sensul mai îngust și aspectualitatea, în sensul mai larg. Limba română nu are categoria gramaticală a aspectului, deoarece nu deține instrumentele gramaticale care ar asigura exprimarea ei în limba română, așa cum a fost în latină sau cum este în limbile preponderent sintetice ca cele slave, de pildă. Însă româna acoperă necesitatea de exprimare a acestei categorii gramaticale prin categoriile lexico-gramaticale ale modurilor desfășurării acțiunii - Aktionsart și ale Terminativității : Aterminativității ce sunt expresia aspectualității în limbă. MID vine, într-un fel, să suplinească și această necesitate de redare a aspectualității în română prin desemnarea unor acțiuni ce au ajuns la punctul final de desfășurarea a lor (perfectul compus, mai mult ca perfectul) sau prin modalitatea de încheiere bruscă a acțiunii (uneori perfectul simplu + semantica verbului), dar și prin consecutivitatea desfășurării diferitor acțiuni.

Prezenta monografie descrie premisele elaborării MID din interiorul paradigmei definite de TP și stabilește metodologia care servește la desfășurarea experimentală și la fundamentarea principiilor de interpretare a datelor empirice, precum și la formularea criteriilor de validare a ipotezelor experimentale și teoretice. TP concepe comunicarea prin intermediul codului lingvistic drept un proces nonautonom, subordonat procesului inferențial. Procesul inferențial, pe de altă parte, este autonom. Comunicarea prin cod este lingvistică, semnalele acustice sau grafice fiind utilizate pentru a comunica reprezentări semantice.

Dacă e să revenim la teoria lui R. Jacobson care afirma că limba e pragmatică, că e cod și la afirmația lui Coșeriu că finalitatea limbii e semnificația și nu codul (Coșeriu, 2009, p. 114), putem conchide că autoarea 
a găsit calea de mijloc care ar îmbina ambele teorii. MID care ar putea juca rolul codului, pe de o parte, și semnificația multiplelor modele de traducere ce țin de gramatica funcțională, dar și de cea generativ-transformațională, pe de altă parte, ar putea crea o înțelegere de ansamblu în soluționarea aspectelor traductologice, pe care și le propune monografia de față.

În lucrarea de față se descrie cum s-a realizat elaborarea și validarea MID în baza limbii franceze, precum și implicațiile teoretice ale MID pentru determinarea dinamicii temporale în limba respectivă. Este prezentată structura ierarhizată a modelului și diversele sale componente. Sunt identificate etapele necesare pentru revalidarea MID și determinarea modului în care calculul inferențial se produce în limba română. Abordarea problemelor enumerate supra nu pot fi soluționate fără apelarea, din nou, la lingvistica integrală a lui Coșeriu, aniversarea a 100 de ani de la a cărui naștere o sărbătorim în acest an. Astfel, când autoarea afirmă că ,,postulatul inițial al MID, bazat pe previziunile TP, este că inferențele direcționale sunt rezultatul combinării informațiilor contextuale cu informațiile lingvistice", apelăm în acest caz la gramatica funcțională și la lingvistica discursului, iar când se afirmă că „MID operează cu informația lingvistică care codifică concepte și informația lingvistică care codifică proceduri”, apelăm la lingvistica cognitivă și la lingvistica vorbirii.

În cazul construirii itemilor experimentali, s-a presupus că cele trei tipuri de informație: conceptuală (predicatele), procedurală morfologică (timpurile) și procedurală propozițională (conectorii), au fost supuse unui șir de variații în baza construcției prototipice e1-e2. Au fost obținute 12 configurații (în baza unei secvențe) de modele transformaționale, constând din două enunțuri. Dacă e să analizăm din punctul de vedere al nivelului vorbirii, aceste variante pot fi sinonimice, dar nu sunt sinonimice la nivelul limbii. De ex., configurați 1 și 2; 3 și 4; 7 și 11; 8 și 12: 1. Anca scăpă paharul din mână. Paharul se sparse. 2. Anca scăpă paharul din mână. Paharul se spărsese;

Sau 3. Paharul se sparse. Anca îl scăpă din mână. 4. Paharul se sparse. Anca îl scăpase din mână.

Sau 8. Paharul se sparse pentru că Anca îl scăpă din mână. 12. Paharul se sparse pentru că Anca îl scăpase din mână.

În traducere avem de a face cu denominarea care se referă la vorbire, cu semnificația, când conținutul este determinat de o limbă concretă și cu sensul, când un conținut concret este exprimat într-un anume text, dar poate exista și fără ele. Exemplele de mai sus, prezentate în cupluri, corespund unei singure denominări, însă nu corespund unei și aceleași semnificații. În astfel de cazuri traducerea depinde de competența lingvistică și experiența traducătorului. Dacă e să ne referim la gramatica vorbirii, cea generativtransformațională, pildele menționate supra Anca a scăpat paharul din mână. Paharul se spărsese. - Anca a scăpat paharul din mână şi paharul se spărsese. - Paharul s-a spart pentru că Anca îl scăpase din mână. corespund unei singuri denominări. Ele sunt ,,sinonime” și pot fi înlocuite între ele în vorbire, deoarece vorbirea se referă la denominare, iar denominarea nu se referă la 
o anumită limbă concretă. În acest caz vorbim de o gramatică a vorbirii și nu de una a limbii. De facto aceste enunțuri nu sunt sinonimice din punctul de vedere al limbii, deoarece au diverse semnificații. Echivalența lor se află în afara nivelului limbii, la nivelul vorbirii. În gramatica structural-funcțională care deservește limba se ia în calcul distincția între enunțuri în limbi concrete, nu echivalența enunțurilor. Această gramatică aplică generalități de folosire a formei, adică stabilește funcțiile limbilor concrete. (Coșeriu, 1993, p. 67). Un traducător ar trebui să fie instruit la nivel de Licență și Masterat în asemenea subtilități,

În concluziile monografiei sunt clarificate particularităților calculului inferențial direcțional în limba română, creând baza teoretică pentru formalizarea unui model de subunitate de traducere direcțională. Astfel, venim cu convingerea că o traducere calificată poate fi realizată doar de traducători cu o solidă pregătire la nivel gnoseologic, în special cu referire la Lingvistica integrală a lui Coșeriu.

\section{Referințe bibliografice:}

1. Coşeriu, Eugen. Lingvistica: starea ei actuală. Revista de lingvistică și știință literară, 1993. 2009.

2. Coșeriu, Eugeniu. Omul și limbajul său. Iași: Editura Universității „A.I. Cuza”,

3. Coșeriu, Eugeniu. Lingvistica textului. O introducere în hermeneutica sensului. Iași: Editura Universității „A.I. Cuza”, 2013.

Notă: Articolul a fost realizat în cadrul proiectului de cercetare 20.80009.1606.01 Valorificarea științifică a patrimoniului lingvistic național în contextul integrării europene, Institutul de Filologie Română „B. P.-Hasdeu” al MEC. 